\title{
Mudflows under changing climate in Zailiysky Alatau, Northern Tien Shan
}

\author{
Roza Yafyazova \\ Republican state-owned enterprise "Kazhydromet" \\ 32, Abay Ave., 050022 Almaty, Republic of Kazakhstan \\ (Email: stepanov@kniimosk.almaty.kz)
}

\begin{abstract}
The influence of climate change on mudflows is evident on the northern slopes of the Zailiysky Alatau Mountain Range. In this area, most of the mudflows occurred during the Riss-Würm interglacial period whereas they nearly stopped during the Riss and Würm Ice Ages. The amount of sediment transported by mudflows to the debris cones located on the foothills increased significantly when the summer air temperature increased by $2-3{ }^{\circ} \mathrm{C}$. Under such conditions, dams are ineffective to control mudflows. Hence, for an effective mudflow control strategy, it is necessary to estimate their frequency and magnitude.
\end{abstract}

\section{INTRODUCTION}

During global warming, mudflows will be most active in the mountains of middle latitudes having a continental climate now. The Tien Shan will be one of such regions. A study of mudflows that occurred in last 150 thousand years on the northern slopes of the Zailiysky Alatau Mountain Range (the Northern Tien Shan) has shown that they nearly stopped during the Ice Ages and their activities were at a maximum during the Riss-Würm interglacial period (Yafyazova 2001). At this time mudflows became active to such an extent that they removed tens of cubic kilometres of sediments to the debris cones for a relatively short time interval (Jouzel et al. 1994). The volume of debris cones formed on the northern foothills of the Zailiysky Alatau nearly doubled (Yafyazova 2002). The analysis of subsurface geology of debris cones revealed that they consist predominantly (more than $90 \%$ ) of mudflow deposits (Fig. 1).

The study of debris cones also showed that there were considerably fewer mudflows during the Holocene. These mudflows contributed to less than $1 \%$ of the total debris cone volume deposited during the Riss-Würm interglacial period (Stepanov and Yafyazova 2002). Therefore, the total mudflow volume of the preceding interglacial periods is close to the mudflow volume of the Riss-Würm interglacial period alone.

\section{CAUSES OF MUDFLOWS IN ZAILIYSKY ALATAU}

The last activation of mudflows on the northern slopes of the Zailiysky Alatau was caused by global warming at the end of the Little Ice Age. The degrading glaciers began to form lakes on their moraine-glacial complexes in the first half of the 20th century. Their evolution lasted for 50-70 years and then, as a rule, they breached with disastrous consequences. On the northern slopes of the Zailiysky Alatau, glacier lake outburst flood-(GLOF) related mudflows took place in 1958, 1963 (the Issyk River basin), 1956, 1973 (the Malay Almatinka River basin; Fig. 2), and 1977 (the Bolshaya Almatinka River basin). The volume of these mudflows varied from 2 to 5 million $\mathrm{m}^{3}$.

The lake (whose development history is shown in Fig. 2 ), breached in 1973 when its volume reached 224 thousand $\mathrm{m}^{3}$. It triggered a mudflow having a density of $2390 \mathrm{~kg} / \mathrm{m}^{3}$ and a volume of 3.8 million $\mathrm{m}^{3}$ (Vinogradov 1976). Presently, a large (220 thousand $\mathrm{m}^{3}$ ) lake on the Glacier Mametova (Fig. 3) poses a serious threat to the Almaty city located on the northern foothills of the Zailiysky Alatau.

The analysis of lacustrine sediments of Lake Issyk testifies that GLOF- and rain-induced mudflows did not form at least in the course of 700 years (till the 20th century) in the most mudflow-prone river basins (e.g. the Issyk River basin) situated on the northern slopes of the Zailiysky Alatau. In the 20th century the activity of rain-induced mudflows increased. Catastrophic rain-induced mudflows took place in 1921, 1947, and 1950. Geological and geomorphic conditions, such as a thick layer of sediments on steep (25$35^{\circ}$ ) slopes, favoured the formation of rain-induced mudflows, which partially destroyed the Riss drift deposits and almost completely swept away the Würm drift deposits lying on $10-20^{\circ}$ slopes. 


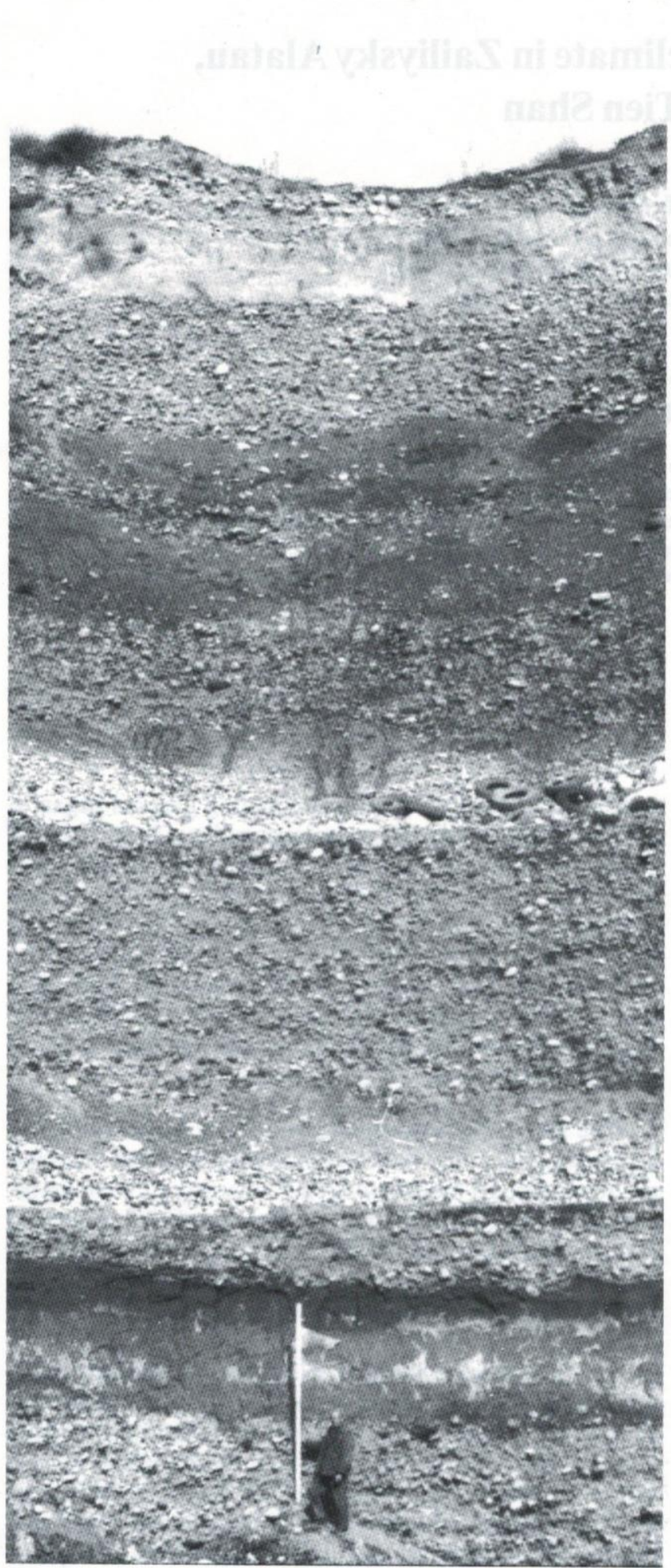

Fig. 1: Outcrop of Aksay River deposits (Zailiysky Alatau Mountain Range)

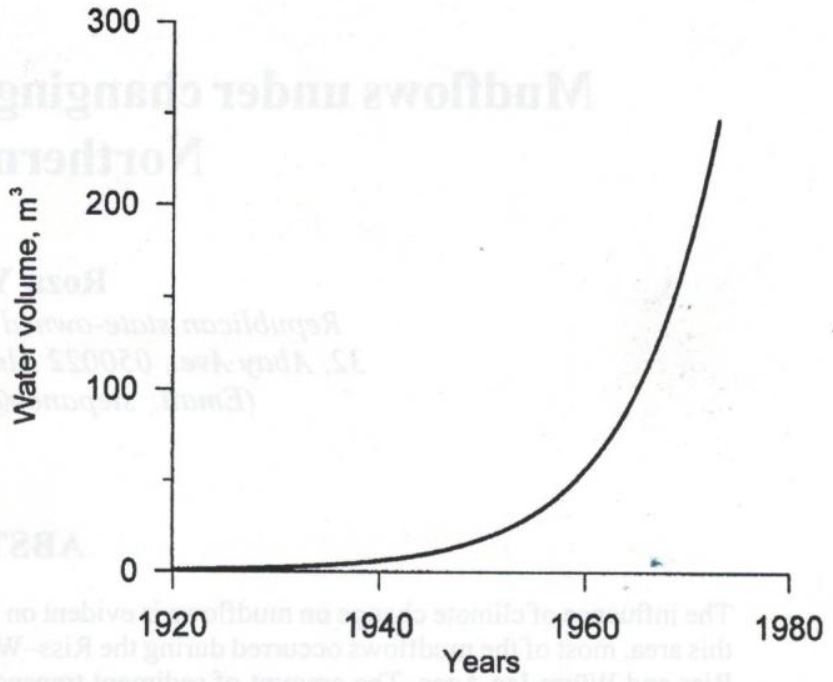

Fig. 2: Change of water volume of Glacier Lake No. 2 located at the Tuyuksu Glacier terminus

A detailed study of climate-controlled exogenous processes in the Northern Tien Shan has shown that its air temperature variation is well correlated with that of Antarctica (the Vostok station). Hence, a decrease in air temperature during the Riss Ice Age by $10-12{ }^{\circ} \mathrm{C}$ in Antarctica can also be attributed to the location of frontal moraines of the same period on the northern slopes of the Zailiysky Alatau. Here, the glaciers descended to altitudes of $1600-1800 \mathrm{~m}$. Nowadays glacier tongues are at altitudes of $3400-3600 \mathrm{~m}$ whereas the glaciers of the Würm Ice Age formed their frontal moraines at altitudes of $2400-2600 \mathrm{~m}$.

The correlation between air temperature variation during the Ice Ages in Antarctica and exogenous processes taking place in the same periods on the northern slopes of the Zailiysky Alatau allows supposing that global warming by $2.6^{\circ} \mathrm{C}$ in the Riss-Würm interglacial period took place both in Antarctica and on the northern slopes of the Zailiysky Alatau. An increase in air temperature by $2.6^{\circ} \mathrm{C}$ was sufficient for almost total deglaciation of the Zailiysky Alatau.

The formation, evolution, and outburst of lakes on the moraine-glacial complexes took place in the course of degradation of glaciers. In all high-altitude zones precipitation took place mainly in liquid phase and resulted in a sharp increase in the frequency and volume of mudflows.

\section{Climate change scenario}

According to the climate change scenario of 2050 developed by the climatologists of Kazakhstan for the mountainous regions of southern and southeastern Kazakhstan, a greater increase (i.e. $1.5-3.5^{\circ} \mathrm{C}$ ) in air temperature is expected than it was in the 20th century. Such an increase in temperature will lead to deglaciation and the activation of mudflows in the mountainous regions of the Northern Tien Shan. However, the role of ice-dammed lakerelated mudflows will be minor. The melting of glaciers and 


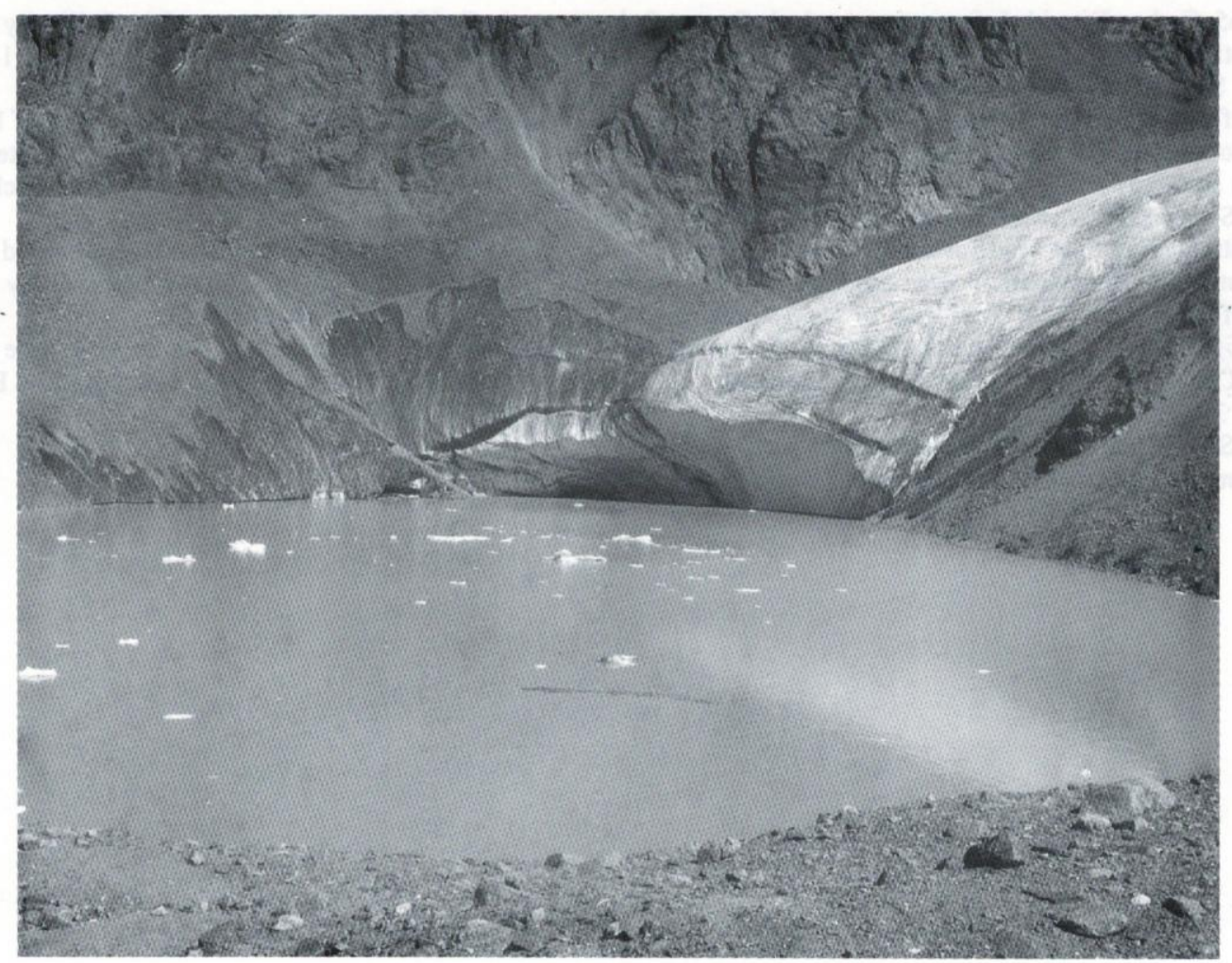

Fig. 3: Lake located on the terminus of the Mametova Glacier. Photo by B. Stepanov.

increase of their number due to disintegration will be accompanied by the formation and evolution of morainedammed lakes. The outburst of these lakes can result in the formation of disastrous mudflows. In the course of deglaciation, GLOFs will gradually decrease in number and subsequently disappear as the glaciers themselves vanish.

On the other hand, rain-induced mudflows will significantly increase in number and they will carry sediments from the higher altitudes to the foothills where the debris cones are located. Such an increase of rain-induced mudflows in the Northern Tien Shan is attributed to the following factors.

- Probability of liquid precipitation in the high altitudes where presently solid precipitation predominates;

- Formation of streams and gullies in the areas covered by snow and ice;

- Increased frequency of rain-induced mudflows (Now mudflows are triggered by a rainfall of $60 \mathrm{~mm}$ and their return period is about 50 to 100 years. If new streams and gullies appear in the glaciated areas, they will saturate the ground making it possible to trigger mudflows at a lower precipitation);

- Protracted time span of mudflow hazard;

- Saturation of fractured rocks due to melting of ice; etc.
The activation of mudflows can lead to the destruction of settlements, desertification of vast territories, and the loss of biodiversity in the mountains and adjoining areas.

\section{CONCLUSIONS}

In Zailiysky Alatau Mountain Range of the Northern Tien Shan, most of the mudflows occurred during the Riss-Würm interglacial period whereas they nearly stopped during the Riss and Würm Ice Ages. When the summer air temperature increased by $2-3^{\circ} \mathrm{C}$, the amount of sediment transported by mudflows to the debris cones located at the foothills increased quite significantly. Present mudflow protection strategy based on its detention by means of dams may become not only ineffective but even dangerous under changing conditions. The existing mudflow-storage reservoirs, when overfilled with sediments, could themselves trigger mudflows. Hence, the measures targeted to the prevention of mudflows or the reduction of their magnitudes could be the better alternatives (Stepanov et al. 2001; Stepanov and Yafyazova 2001).

\section{REFERENCES}

Jouzel, J., Lorius, C., Petit, J. R., Barkov, N. I., and Kotlyakov, V. M., 1994, Vostok isotopic temperature record. In: T. A. Boden, D. P. Kaiser, R. J. Sepanski, and F. W. Stoss (eds.), Trends '93: A Compendium of Data on Global Change: 590-602. ORNL/ 
CDIAC-65. Carbon Dioxide Information Analysis Center, Oak Ridge National Laboratory, Oak Ridge, Tenn., USA.

Stepanov, B. S. and Yafyazova, R. K., 2002, Holocene climate and mudflow activity in the northern slope of the Zailiysky Alatau Mountains. Hydrometeorology and Ecology, no. 1, pp. 74-81 (in Russian).

Stepanov, B. S. and Yafyazova, R. K., 2001, Radical review of the defence strategy against mudflows is a necessary condition for the sustainable development of the mountain and piedmont regions of Kazakhstan. In: Problems of Hydrometeorology and Ecology; Proceedings of the International Scientific and Practical Conference, Almaty, Kazakhstan, September 12-13, 2001, pp. 32-35 (in Russian).

Stepanov, B. S., Khaidarov, A. Kh., and Yafyazova, R. K., 2001, Mechanisms which provoke forming rainfall-caused mudflows in the high-mountain zone of the Zailiysky Alatau Mountains. Hydrometeorology and Ecology, nos. 1-2, pp. 74-81 (in Russian).

Vinogradov, Yu. B., 1976, The debris flow of 15 July 1973 in the Little Almatinka. Debris Flows, Collected papers, Kazakh Institute for Hydrometeorological Research, no. 1, pp. 60-72 (in Russian).

Yafyazova, R. K., 2001, Global warming and mudflow activity. Adaptation problems. Hydrometeorology and Ecology, no. 3-4 pp. 97-106 (in Russian).

Yafyazova, R. K., 2002, Debris cone volume as an indicator of mudflow activity. Hydrometeorology and Ecology, no. 2, pp. 90-99 (in Russian). 